\title{
Synthesis of $2 H$-pyran-2-ones and fused pyran-2-ones as useful building blocks
}

\author{
Franc Požgan, Krištof Kranjc, Vladimir Kepe ${ }^{\dagger}$, Slovenko Polanc, and Marijan Kočevar* \\ Faculty of Chemistry and Chemical Technology, University of Ljubljana, Aškerčeva 5, SI-1000 \\ Ljubljana, Slovenia \\ E-mail: marijan.kocevar@ffkkt.uni-lj.si
}

\section{Dedicated to Professor Waldemar Adam on the occasion of his $\mathbf{7 0}^{\text {th }}$ birthday}

\begin{abstract}
A one-pot synthesis of 3-benzoylamino derivatives of 5- to 8-membered cycloalka[b]pyran-2ones $\mathbf{5}$ and $2 H$-pyran-2-ones 10, starting from the appropriate alkanones $\mathbf{1}$ and $\mathbf{8}$, respectively, $N, N$-dimethylformamide dimethyl acetal (DMFDMA) and hippuric acid in the presence of a large excess of acetic anhydride, is described. A comparison of conventional thermal activation with microwave activation is given in the case of synthesis of $\mathbf{5 c}$. The benzoyl protective group on amino moiety of the fused pyran-2-ones $\mathbf{5}$ and derivatives $\mathbf{1 1}$ was successfully removed by gentle heating in sulfuric acid resulting in the formation of the corresponding 3aminocycloalka[b]pyran-2-ones 7 and 3-amino-2H-pyran-2-ones 12 in high yield.
\end{abstract}

Keywords: Heterocycles, 2H-pyran-2-ones, fused pyran-2-ones, benzamides, microwave activation, $\alpha$-enaminoketones

\section{Introduction}

The importance of pyran-2-one derivatives as building blocks in the field of synthetic and medicinal chemistry has been well established and is a consequence of their interesting structural features and diverse pharmacological properties. ${ }^{1}$ The pyran-2-one ring is highly susceptible to nucleophilic attack at the electrophilic centers C-2, C-4 and C-6, and a variety of synthetic approaches for preparation of arenes and heteroarenes starting from pyran-2-ones has been developed. ${ }^{2}$ Reactions of $2 \mathrm{H}$-pyran-2-ones with different dienophiles, have been widely investigated and utilized for the preparation of a multitude of heterocyclic or carbocyclic products. ${ }^{3}$

\footnotetext{
${ }^{\dagger}$ Current address: Department of Molecular and Medical Pharmacology, David Geffen School of Medicine at UCLA, Los Angeles, CA 90095, U.S.A
} 
The presence of 3-amino group on 2H-pyran-2-ones or fused pyran-2-ones opens additional possibilities for their utilization as building blocks in heterocyclic chemistry. Recently, we have described transformations of 3-benzoylamino derivatives of $2 \mathrm{H}$-pyran-2-ones and fused pyran-2ones with maleic anhydride ${ }^{4 a, b}$ and maleimides ${ }^{4 c, d}$ under the conditions of the Diels-Alder reaction yielding different bicyclo[2.2.2]oct-7-enes and benz[e]isoindoles. We have also transformed several 3-benzoylamino-2H-pyran-2-ones into highly substituted aniline, biphenyl and terphenyl derivatives in reactions with a variety of alkynes under thermal reaction conditions, using high pressures or under the influence of microwaves. ${ }^{4-\mathrm{g}}$ Similarly, 3-amino$2 \mathrm{H}$-pyran-2-ones and 3-amino derivatives of fused pyran-2-ones have been transformed into pyridazine derivatives via a novel reaction. ${ }^{5}$ Since many of the 3-benzoylamino and 3-amino compounds we applied for some of the above-mentioned transformations have not yet been properly described, but only short notes about their syntheses were given previously, ${ }^{4 a, c, d, f, g, 5 b, c}$ we report here high-yield synthetic procedures for the preparation of these compounds and their full characterization data.

$2 \mathrm{H}$-Pyran-2-ones and fused pyran-2-ones can be prepared by a variety of methods depending on the substitution pattern of the desired compounds. ${ }^{1}$ In the past we developed a onepot synthesis of 3-acylamino derivatives of a wider variety of pyran-2-one ring containing systems. ${ }^{6}$ This synthetic procedure requires compounds with highly activated methylene or methyl group (1,3-dicarbonyl compounds, methyl ketones, lactones, thiolactone or lactam) which are reacted with a one-carbon building block (DMFDMA, triethyl orthoformate, diethoxymethyl acetate, or $N, N$-dimethylacetamide dimethyl acetal) and an $N$-acylglycine in acetic anhydride.

Herein we describe a modification of this procedure which is applicable for the transformation of less activated ketones, such as cycloalkanones and arylacetones, into the corresponding 3-benzoylamino-substituted pyran-2-one derivatives in high yield. Some of these compounds, as well as some of previously described 3-benzoylamino-2H-pyran-2-ones, ${ }^{6}$ can be effectively de-benzoylated in sulfuric acid yielding a series of the corresponding 3-amino compounds in high yield. The target products thus obtained have been used in a variety of the above-mentioned transformations.

\section{Results and Discussion}

We started our investigation with the application of a one-pot methodology toward the synthesis of a series of cycloalka[b]pyran-2-ones 5a-d and 5-aryl-6-methyl-2H-pyran-2-one derivatives $\mathbf{1 0 a}, \mathbf{b}$. In the first step cycloalkanones 1 were heated with two equivalents of DMFDMA for $16 \mathrm{~h}$ to prepare previously described $\alpha$-enaminoketones 2 . $^{7}$ Products 2 have not been isolated in the pure state, only the remaining DMFDMA and eliminated methanol were evaporated in vacuo. To the crude intermediate 2 hippuric acid and acetic anhydride were added and the reaction mixture was heated at $90{ }^{\circ} \mathrm{C}$ for $4 \mathrm{~h}$. Upon concentration, addition of ethanol to the oily residue and cooling, the separated solid was filtered off to give a mixture of two products; namely, the 
expected fused pyran-2-one derivative $\mathbf{5}$ and the oxazolone derivative $\mathbf{6}$. For example, with the starting 1a the ratio of 5a to 6a was $2.8: 1$ (as determined from the ${ }^{1} \mathrm{H}$ NMR spectrum of the crude reaction mixture), and with $\mathbf{1 b}$ the ratio $\mathbf{5 b}: \mathbf{6} \mathbf{b}$ was $1: 1$. We believe that unexpected products $\mathbf{6 a}, \mathbf{b}$ appeared in a competing reaction (to the formation of $\mathbf{5 a}, \mathbf{b}$ ) by the acetylation of the intermediates $\mathbf{4}$ with acetic anhydride. Compounds $\mathbf{4}$ can exist in a series of tautomeric forms also possessing different configurations around exocyclic double bonds and, as a consequence, this opens up possibilities for a variety of reactions. The configuration of the exocyclic oxazolone double bond in products $\mathbf{6 a}, \mathbf{b}$ was determined on the basis of the coupled ${ }^{13} \mathrm{C}$ NMR spectrum. Namely, the magnitude of the coupling constant between the oxazolone carbon 5-C and vicinal proton of the exocyclic $\mathrm{CH}$ group was determined to be $4.6 \mathrm{~Hz}$ at $167.9 \mathrm{ppm}$ for $\mathbf{6 a}$ and $5.5 \mathrm{~Hz}$ at $168 \mathrm{ppm}$ for $\mathbf{6 b}$. These values are typical for the $(Z)$-isomers. ${ }^{8 \mathrm{a}-\mathrm{c}}$ The $(Z)$-structure of $\mathbf{6 a , b}$ is also supported by the chemical shifts of $\beta-\mathrm{H}$ atoms at the exocyclic double bond of the compounds $\mathbf{6 a , b}$ (7.15 and $7.17 \mathrm{ppm}$ for $\mathbf{6 a}$ and $\mathbf{6 b}$, respectively), which is the same as that of the related (4Z)-4-(3,4-dimethoxybenzylidene)-2-phenyloxazol-5(4H)-one $(7.15 \mathrm{ppm}){ }^{8 \mathrm{~d}}$

Next we investigated a possibility of transformation of oxazolone derivatives 6 into fused pyran-2-ones 5. The oxazolone derivative $\mathbf{6 b}$ was transformed on heating for $10 \mathrm{~h}$ in boiling pyridine into pyran-2-one 5b. Similarly, an equimolar mixture of compounds $\mathbf{5 b}$ and $\mathbf{6 b}$ was heated for $6 \mathrm{~h}$ in a mixture of pyridine and triethylamine to give fused pyran-2-one $\mathbf{5 b}$ almost quantitatively. We believe that during this process the acetyl moiety is removed from the cyclohexene unit to give intermediate 4 , and the latter cyclizes to the pyran-2-one derivative.

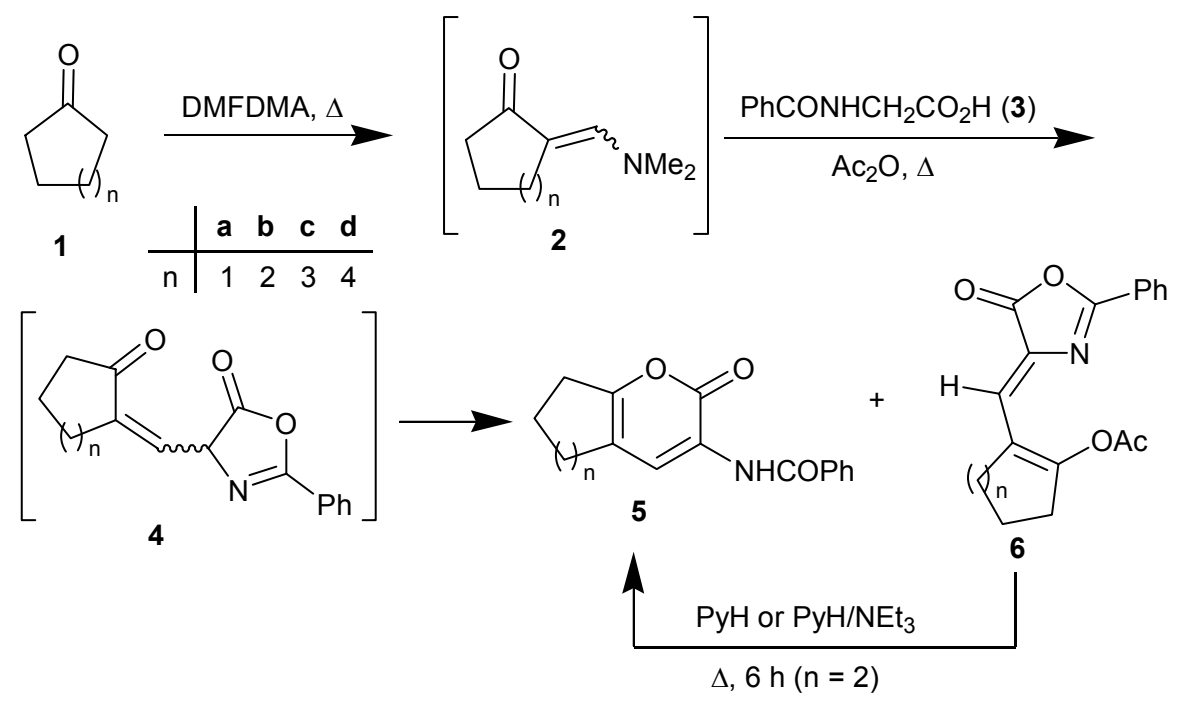

\section{Scheme 1}

With the above results in hand, we have developed a new modification of the one-pot methodology for the synthesis of $\mathbf{5 a}-\mathbf{d}$, which, in the first step, requires conversion of the monoactivated cycloalkanones $\mathbf{1 a}-\mathbf{d}$ into the corresponding $\alpha$-enaminoketones $\mathbf{2 a}-\mathbf{d}$ with a 
twofold excess of DMFDMA under reflux for $16 \mathrm{~h}$ (step 1). After evaporation of the volatile components crude 2-[(dimethylamino)methylene]cycloalkanones were reacted with hippuric acid (equimolar amount to starting alkanone) in acetic anhydride at $90{ }^{\circ} \mathrm{C}$ for $4 \mathrm{~h}$ (step 2). Further evaporation of volatile components afforded tarry residues which were treated with a mixture of pyridine and triethylamine under reflux for $9 \mathrm{~h}$ (step 3). Upon evaporation, ethanol was added to the residue and the products 5a-d were isolated in 60-73\% yields in crystalline form (Scheme 2 ). These yields are generally significantly higher than those obtained by previously ${ }^{6}$ published modifications. It is of interest to note that the compound $\mathbf{5} \mathbf{b}$ was already prepared in a two-step process from 4-ethoxymethylene-2-phenyloxazol-5(4H)-one and 1-piperidinocyclohexene. ${ }^{9}$

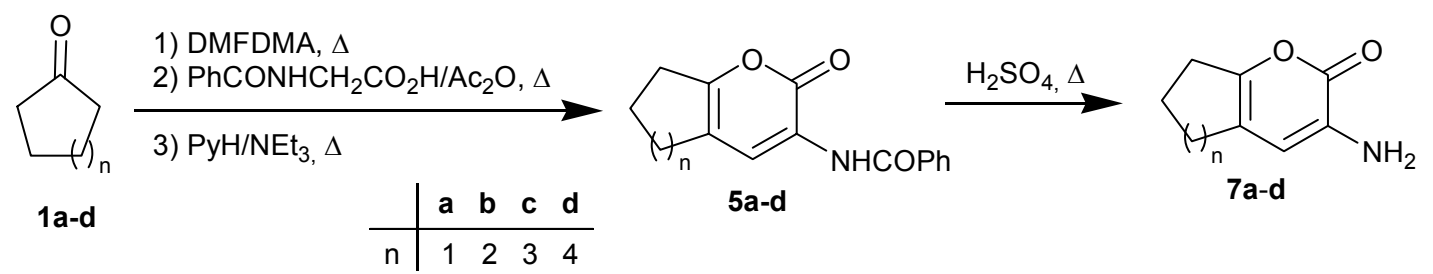

\section{Scheme 2}

During recent years, the application of microwaves as a green source of heating is of increasing importance in organic synthesis. ${ }^{10}$ Therefore, on the basis of our previously reported results ${ }^{4 b, d, g, 11 a, b}$ and the results of others, ${ }^{11 \mathrm{c}-\mathrm{f}}$ we tested the synthesis of $\mathbf{5 c}$ also under microwave irradiation conditions. With the use of a closed reaction vessel and higher reaction temperatures $\left(130{ }^{\circ} \mathrm{C}\right)$ we have been able to significantly reduce the reaction times in all three steps. We managed to reduce the total time of heating from $29 \mathrm{~h}$ under conventional reaction condition to $10 \mathrm{~h}$ under microwave irradiation with a negligible change in the yield on $10 \mathrm{mmol} \mathrm{scale}(65 \%$ versus $62 \%$ yield).

In addition to monoactivated cycloalkanones we have also applied the one-pot synthetic procedure for the conversion of sterically hindered ketones, such as arylacetones $\mathbf{8}$, in order to prepare $2 \mathrm{H}$-pyran-2-ones 10a,b containing a large electron-donating substituent in position 5 (Scheme 3). Here, we started from aryl-substituted acetone derivatives 8, DMFDMA and hippuric acid in acetic anhydride. For the successful preparation of the products 10a,b only modified steps 1 and 2 from the above method were required and the target compounds were isolated in high yields (78-81\%). The intermediate $\alpha$-enaminoketones $9^{12}$ have not been isolated in the pure state during this process. Though the reactive site (the methylene group) of arylacetones applied in this investigation is sterically much more hindered than the methyl group of aryl methyl ketones, ${ }^{6 \mathrm{f}}$ here products $\mathbf{1 0}$ were isolated in higher yields than previously prepared 6-substituted 2H-pyran-2-ones. The products 10 thus obtained exhibit a novel pattern of substituents (i. e. 3-amino-5-aryl-6-methyl-) of 2H-pyran-2-one system. 


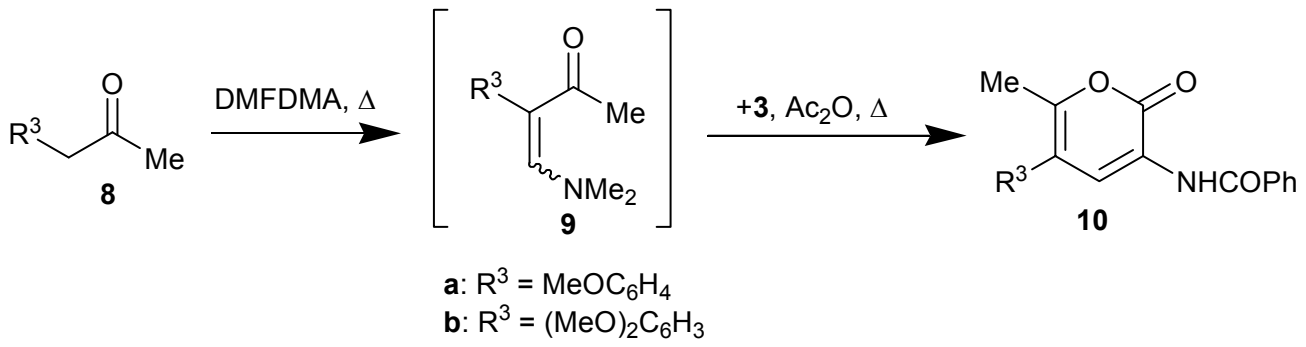

\section{Scheme 3}

The benzoylamino moiety of fused pyran-2-ones $\mathbf{5} \mathbf{a}^{-} \mathbf{- d}$ was deprotected by gentle heating in concentrated sulfuric acid, ${ }^{13}$ followed by the aqueous work-up, thus giving rise to 3 -amino derivatives 7a-d in $79-92 \%$ yield (see Scheme 2). The same method is applicable for the preparation of simple 3-amino-6-substituted- and 3-amino-4,6-disubstituted-2 $\mathrm{H}$-pyran-2-ones 12a-e from the appropriate 3-benzoylamino precursors 11a-e (Scheme 4). The starting derivatives $\mathbf{1 1}$ were heated in concentrated sulfuric acid (as above) and after the work-up the corresponding products $\mathbf{1 2}$ were successfully isolated in $78-97 \%$ yield. The product $\mathbf{1 2 b}$ was previously prepared by the reduction of 3-nitro-6-phenyl-2H-pyran-2-one. ${ }^{14}$

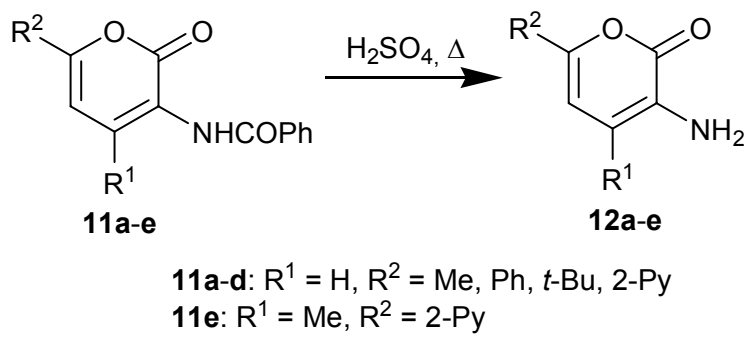

\section{Scheme 4}

\section{Conclusions}

We have developed a one-pot synthesis for the preparation of 5- to 8-membered cycloalkenefused pyran-2-one derivatives 5 starting from the appropriate cycloalkanones, DMFDMA and hippuric acid in the presence of a large excess of acetic anhydride. A modified one-pot methodology was also used for the preparation of $\mathrm{N}$-(5-aryl-6-methyl-2-oxo- $2 \mathrm{H}$-pyran-3yl)benzamides 10. The benzoylamino moiety of the compounds 5 was successfully deprotected by gentle heating in sulfuric acid to give the corresponding 3-aminocycloalka[b]pyran-2-ones 7 . Similarly, a variety of 3-amino-6-substituted- and 3-amino-4,6-disubstituted-2 $H$-pyran-2-ones $\mathbf{1 2}$ was also obtained from 11 on heating with sulfuric acid. These two high yielding synthetic procedures represent useful ways for the preparation of benzoylamino and amino derivatives of 
pyran-2-ones, often used building blocks in synthetic organic chemistry, as previously shown by their fruitful application in a variety of transformations. ${ }^{4 a, c, d, f, g, 5 b, c}$

\section{Experimental Section}

General Procedures. Melting points were determined on a Kofler micro hot stage, and are uncorrected. ${ }^{1} \mathrm{H}$ and ${ }^{13} \mathrm{C}$ NMR spectra were recorded at $29{ }^{\circ} \mathrm{C}$ in DMSO- $d_{6}$ or $\mathrm{CDCl}_{3}$ with a Bruker Avance DPX 300 spectrometer, using TMS as an internal standard. The coupling constants $(J)$ are given in Hz. 2D NMR experiments $\left({ }^{1} \mathrm{H}-{ }^{1} \mathrm{H}\right.$ and $\left.{ }^{1} \mathrm{H}-{ }^{13} \mathrm{C}\right)$ were performed in order to fully assign the structures of the 3-benzoylamino compounds $\mathbf{5}$ and 10. IR spectra were obtained with a Bio-Rad FTS 3000 MX spectrophotometer. Mass spectra were recorded with a VG-Analytical AutoSpec Q instrument. Elemental analyses (C, H, N) were performed with a Perkin-Elmer $2400 \mathrm{CHNS} / \mathrm{O}$ analyzer. TLC was carried out on Fluka silica-gel TLC sheets. Microwave reactions were conducted in air using a focused microwave unit (Discover by CEM Corporation, Matthews, NC). The machine consists of a continuous, focused microwave power delivery system with an operator-selectable power output from 0 to $300 \mathrm{~W}$. Reactions were performed in a glass vessels (capacity $10 \mathrm{~mL}$ ) sealed with a septum. The pressure was controlled by a load cell connected to the vessel via septum. The temperature of the contents of the vessel was monitored using a calibrated infrared temperature controller mounted under the reaction vessel. The mixtures were stirred with a Teflon-coated magnetic stirring bar in the vessel. Temperature, pressure and power profiles were recorded using commercially available software provided by the manufacturer of the microwave unit. Starting 3-benzoylamino compounds 11 were prepared as described previously. ${ }^{6}$ Other reagents and solvents were used as obtained from the commercial sources.

\section{General procedure for the synthesis of $5 a-d$}

(a) Conventional heating. A mixture of a cycloalkanone 1a-d $(50 \mathrm{mmol})$ and DMFDMA $(11.917 \mathrm{~g}, 100 \mathrm{mmol})$ was refluxed for $16 \mathrm{~h}$. The volatile components were removed under reduced pressure and the crude 2-[(dimethylamino)methylene]cycloalkanone $\mathbf{2 a}-\mathbf{d}$ was reacted with hippuric acid $(8.959 \mathrm{~g}, 50 \mathrm{mmol})$ in acetic anhydride $(65 \mathrm{~mL})$ at $90{ }^{\circ} \mathrm{C}$ for $4 \mathrm{~h}$. The volatile components were removed under reduced pressure, a mixture of pyridine $(50 \mathrm{~mL})$ and triethylamine $(12.5 \mathrm{~mL})$ was added, and the resulting solution refluxed for $9 \mathrm{~h}$. After the removal of the volatile components the residue was treated with ethanol $(40 \mathrm{~mL})$ and, after prolonged cooling (3-5 days), the precipitate was filtered off and washed with a small amount of ethanol (4 $\mathrm{mL}$ ) to afford the corresponding products $\mathbf{5} \mathbf{a}-\mathbf{d}$.

(b) Microwave heating. A mixture of cycloalkanone 1c (1.122 g, $10 \mathrm{mmol})$ and DMFDMA $\left(2.383 \mathrm{~g}, 20 \mathrm{mmol}\right.$ ) was irradiated with microwaves for $4 \mathrm{~h}$ (final temperature $130{ }^{\circ} \mathrm{C}$, power 100 $\mathrm{W}$, ramp time $5 \mathrm{~min}$ ). The volatile components were removed under reduced pressure and to the crude 2-[(dimethylamino)methylene]cycloheptanone (2c), hippuric acid (1.792 g, $10 \mathrm{mmol})$ and 
acetic anhydride $(2.5 \mathrm{~mL})$ were added and irradiated with microwaves for $2 \mathrm{~h}$ (final temperature $130{ }^{\circ} \mathrm{C}$, power $60 \mathrm{~W}$, ramp time $5 \mathrm{~min}$ ). The volatile components were removed under reduced pressure and a mixture of pyridine and triethylamine $(4: 1,2.5 \mathrm{~mL})$ was added. The reaction mixture was irradiated for $4 \mathrm{~h}$ (final temperature $130{ }^{\circ} \mathrm{C}$, power $60 \mathrm{~W}$, ramp time $5 \mathrm{~min}$ ), then it was evaporated to dryness under reduced pressure and ethanol $(8 \mathrm{~mL})$ was added. Upon prolonged cooling (3-5 days), the precipitate was filtered off and washed with a small amount of ethanol ( $1 \mathrm{~mL})$ to afford the product $5 \mathbf{c}(1.585 \mathrm{~g}, 62 \%)$.

Transformation of enaminoketones $2 \mathrm{a}, \mathrm{b}$ to fused pyran-2-ones $5 \mathbf{5}, \mathrm{b}$ and oxazolones $6 \mathrm{a}, \mathrm{b}$ A mixture of crude 2-[(dimethylamino)methylene]cyclopentanone (2a, $2.79 \mathrm{~g}, 20.0 \mathrm{mmol})$ or 2[(dimethylamino)methylene]cyclohexanone (2b, $2.64 \mathrm{~g}, 17.2 \mathrm{mmol})$, hippuric acid (for $2 \mathrm{a}: 3.60$ g, $20.0 \mathrm{mmol}$ or for $\mathbf{2 b}: 3.10 \mathrm{~g}, 17.2 \mathrm{mmol}$ ) and acetic anhydride (for $\mathbf{2 a :} 25 \mathrm{~mL}$ or for $\mathbf{2 b}: 14$ $\mathrm{mL}$ ) was heated at $90^{\circ} \mathrm{C}$ for $4 \mathrm{~h}$. The volatile components were removed in vacuo, EtOH (for $\mathbf{2 a}$ : $10 \mathrm{~mL}$ or for $\mathbf{2 b}: 9 \mathrm{~mL}$ ) was added and the resulting mixture was cooled. The precipitated solid was filtered off and washed with EtOH.

For 2a. A mixture (2.54 g) of fused pyran-2-one 5a and oxazolone 6a was obtained (molar ratio $2.8: 1$, from ${ }^{1} \mathrm{H}$ NMR spectrum). Products separation by column chromatography on silicagel (light petroleum / ethyl acetate $=5: 1)$ yielded oxazolone $6 \mathbf{a}(248 \mathrm{mg}, 0.8 \mathrm{mmol})$, fused pyran-2one $5 \mathbf{a}(650 \mathrm{mg}, 2.5 \mathrm{mmol})$ and a residual mixture of both $(1.24 \mathrm{~g})$.

For $\mathbf{2 b}$. A mixture $(1.87 \mathrm{~g}$ ) of fused pyran-2-one $\mathbf{5 b}$ and oxazolone $\mathbf{6 b}$ was obtained (molar ratio 1 : 1 , from ${ }^{1} \mathrm{H}$ NMR spectrum). Products separation by column chromatography on silicagel (light petroleum / ethyl acetate $=5: 1)$ yielded oxazolone $6 \mathbf{b}(217 \mathrm{mg}, 0.7 \mathrm{mmol})$, fused pyran-2one $5 \mathbf{b}(383 \mathrm{mg}, 1.4 \mathrm{mmol})$ and a residual mixture of both $(940 \mathrm{mg})$.

\section{Conversion of oxazolone $6 \mathrm{~b}$ into fused pyran-2-one $5 \mathrm{~b}$}

A mixture of oxazolone $\mathbf{6 b}(118 \mathrm{mg}, 0.38 \mathrm{mmol})$ and pyridine $(2 \mathrm{~mL})$ was refluxed for $10 \mathrm{~h}$. Thereafter, the volatile components were removed in vacuo and the residue was separated by radial chromatography on silicagel (light petroleum / ethyl acetate $=5: 1)$ yielding $43 \mathrm{mg}(42 \%)$ of fused pyran-2-one $\mathbf{5 b}$.

\section{Conversion of a mixture of fused pyran-2-one $5 \mathrm{~b}$ and oxazolone $6 \mathrm{~b}$ into $5 \mathrm{~b}$}

A previously obtained mixture $(182 \mathrm{mg})$ of oxazolone $\mathbf{6 b}$ and fused pyran-2-one $\mathbf{5 b}$ (approximate molar ratio $1: 1)$ in pyridine $(4 \mathrm{~mL})$ and triethylamine $(0.5 \mathrm{~mL})$ was refluxed for 6 h. Thereafter, the volatile components were removed in vacuo, $\mathrm{MeOH}$ was added and the precipitated solid was filtered off yielding $125 \mathrm{mg}(0.46 \mathrm{mmol})$ of fused pyran-2-one $\mathbf{5 b}$.

\section{General procedure for the synthesis of 10a,b}

A mixture of (4-methoxyphenyl)acetone or (3,4-dimethoxyphenyl)acetone (86 mmol) and DMFDMA (21.45 g, $180 \mathrm{mmol})$ was refluxed for $4 \mathrm{~h}$. The volatile components were removed in vacuo, hippuric acid $(15.41 \mathrm{~g}, 86 \mathrm{mmol})$ and acetic anhydride $(110 \mathrm{~mL})$ were added and the mixture was heated at $90{ }^{\circ} \mathrm{C}$ for $4 \mathrm{~h}$. Thereafter, the volatile components were removed in vacuo, EtOH $(55 \mathrm{~mL})$ was added and cooled to $-18{ }^{\circ} \mathrm{C}$. The precipitated solid was filtered off and washed with EtOH. 
General procedure for the synthesis of $7 \mathbf{a}-\mathbf{d}$ and $12 \mathrm{a}-\mathbf{e}$. A mixture of a 3-benzoylaminopyran-2-one derivative $5 \mathbf{a}-\mathbf{d}$ or $11 \mathbf{a}-\mathbf{e}(5 \mathrm{mmol})$ and $5 \mathrm{~mL}$ of concentrated $\mathrm{H}_{2} \mathrm{SO}_{4}$ was heated at $60-65{ }^{\circ} \mathrm{C}$ for $2 \mathrm{~h}$. Upon cooling and adding $50 \mathrm{~g}$ of water-ice mixture, the precipitated benzoic acid was filtered off. The filtrate was neutralized with $\mathrm{NaHCO}_{3}$ and the precipitated product was filtered off. For the isolation of the products 12a,c extraction with $\mathrm{CH}_{2} \mathrm{Cl}_{2}$ was used. For the isolation of the product $\mathbf{1 2 b}$ the precipitated material, formed after the addition of water-ice mixture, is filtered off, dispersed in water and neutralized with $\mathrm{Na}_{2} \mathrm{CO}_{3}$. Precipitated product $\mathbf{1 2 b}$ is then filtered off.

\section{Analytical and spectroscopic data of the products.}

$\boldsymbol{N}$-(2-Oxo-2,5,6,7-tetrahydrocyclopenta[b]pyran-3-yl)benzamide (5a). This compound (9.308 g, 73\%) was obtained as long brown needles (EtOH), mp $177-179{ }^{\circ} \mathrm{C}$; Anal. Calcd. $\mathrm{C}_{15} \mathrm{H}_{13} \mathrm{NO}_{3}$ : C, 70.58; H, 5.13; N, 5.49. Found: C, 70.41; H, 5.09; N, 5.42; IR (KBr, $\left.\mathrm{cm}^{-1}\right)$ 3356, 1705, 1663 , 1638, 1525; ${ }^{1} \mathrm{H}-\mathrm{NMR}\left(300 \mathrm{MHz}, \mathrm{CDCl}_{3}\right) \delta 2.15\left(2 \mathrm{H}, \mathrm{m}, 6 \mathrm{C}^{\prime}-\mathrm{CH}_{2}\right), 2.73\left(2 \mathrm{H}, \mathrm{m}, 5^{\prime}-\mathrm{CH}_{2}\right), 2.82$ $\left(2 \mathrm{H}, \mathrm{m}, 7^{\prime}-\mathrm{CH}_{2}\right), 7.53$ (3H, m, Ph), 7.89 (2H, m, Ph), 8.45 (1H, s, 4'-H), 8.65 (1H, br. s, NH); ${ }^{13} \mathrm{C}-\mathrm{NMR}\left(75.5 \mathrm{MHz}, \mathrm{CDCl}_{3}\right) \delta 20.8,28.6,30.6,116.7,122.9,123.9,127.1,128.9,132.3,133.9$, 156.2, 161.1, 166.0; MS m/z: $255\left(\mathrm{M}^{+}, 57 \%\right), 105$ (100\%).

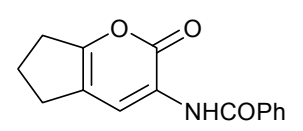

$\mathrm{N}$-(2-Oxo-5,6,7,8-tetrahydro-2H-chromen-3-yl)benzamide (5b). This compound (8.340 g, $62 \%)$ was obtained as off-white cubiform crystals $\left(\mathrm{MeOH} / \mathrm{CHCl}_{3}\right), \mathrm{mp} 124-125{ }^{\circ} \mathrm{C}\left(\mathrm{mp}^{9} 123\right.$ $\left.{ }^{\circ} \mathrm{C}\right)$; Anal. Calcd. $\mathrm{C}_{16} \mathrm{H}_{15} \mathrm{NO}_{3}$ : C, 71.36; H, 5.61; N, 5.20. Found: C, 71.18; H, 5.59; N, 5.24; IR $\left(\mathrm{KBr}, \mathrm{cm}^{-1}\right) 3358,2941,1705,1661,1645,1523 ;{ }^{1} \mathrm{H}-\mathrm{NMR}\left(300 \mathrm{MHz}, \mathrm{CDCl}_{3}\right) \delta 1.79\left(4 \mathrm{H}, \mathrm{m}, 6^{\prime}-\right.$ $\left.\mathrm{CH}_{2}, 7^{\prime}-\mathrm{CH}_{2}\right), 2.47\left(2 \mathrm{H}, \mathrm{m}, 5^{\prime}-\mathrm{CH}_{2}\right), 2.54\left(2 \mathrm{H}, \mathrm{m}, 8^{\prime}-\mathrm{CH}_{2}\right), 7.51(3 \mathrm{H}, \mathrm{m}, \mathrm{Ph}), 7.88$ (2H, m Ph), $8.24\left(1 \mathrm{H}, \mathrm{s}, 4^{\prime}-\mathrm{H}\right), 8.64$ (1H, br. s, NH); ${ }^{13} \mathrm{C}-\mathrm{NMR}\left(75.5 \mathrm{MHz}, \mathrm{CDCl}_{3}\right) \delta 21.8,22.1,26.1,26.9$, $113.3,123.1,127.08,127.12,128.9,132.3,133.8,152.6,160.3,166.0 ; \mathrm{MS} m / z: 269\left(\mathrm{M}^{+}, 41 \%\right)$, $105(100 \%)$.

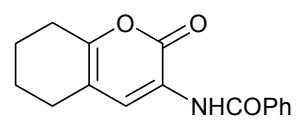

$\boldsymbol{N}$-(2-Oxo-2,5,6,7,8,9-hexahydrocyclohepta[b]pyran-3-yl)benzamide (5c). This compound $(9.200 \mathrm{~g}, 65 \%)$ was obtained as pinkish orange platelike crystals $\left(\mathrm{MeOH} / \mathrm{CHCl}_{3}\right), \mathrm{mp} 138-140$ ${ }^{\circ} \mathrm{C}$; Anal. Calcd. $\mathrm{C}_{17} \mathrm{H}_{17} \mathrm{NO}_{3}$ : C, 72.07; H, 6.05; N, 4.94. Found: C, 71.99; H, 6.25; N, 4.82; IR $\left(\mathrm{KBr}, \mathrm{cm}^{-1}\right)$ 3354, 2918, 1699, 1661, 1636, 1560, 1528; ${ }^{1} \mathrm{H}-\mathrm{NMR}\left(300 \mathrm{MHz}, \mathrm{CDCl}_{3}\right) \delta 1.67(4 \mathrm{H}$, m) and $1.82(2 \mathrm{H}, \mathrm{m})\left(6^{\prime}-\mathrm{CH}_{2}, 7^{\prime}-\mathrm{CH}_{2}, 8^{\prime}-\mathrm{CH}_{2}\right), 2.55\left(2 \mathrm{H}, \mathrm{m}, 5^{\prime}-\mathrm{CH}_{2}\right), 2.73\left(2 \mathrm{H}, \mathrm{m}, 9^{\prime}-\mathrm{CH}_{2}\right), 7.53$ $(3 \mathrm{H}, \mathrm{m}, \mathrm{Ph}), 7.89$ (2H, m, Ph), 8.34 (1H, s, 4'-H), 8.61 (1H, br. s, NH); ${ }^{13} \mathrm{C}-\mathrm{NMR}(75.5 \mathrm{MHz}$, $\left.\mathrm{CDCl}_{3}\right) \delta 25.0,26.7,31.5,31.7,33.7,118.6,122.4,127.1,128.9,129.3,132.3,133.8,157.8$, 160.2, 166.0; MS m/z: $283\left(\mathrm{M}^{+}, 50 \%\right), 105$ (100\%). 


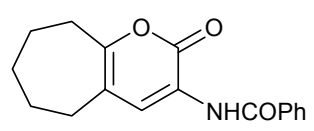

$\boldsymbol{N}$-(2-Oxo-5,6,7,8,9,10-hexahydro-2H-cycloocta[b]pyran-3-yl)benzamide $\quad$ (5d). This compound $(8.910 \mathrm{~g}, 60 \%)$ was obtained as pale orange crystals $\left(\mathrm{MeOH} / \mathrm{CHCl}_{3}\right), \mathrm{mp} 127-130$ ${ }^{\circ} \mathrm{C}$; Anal. Calcd. $\mathrm{C}_{18} \mathrm{H}_{19} \mathrm{NO}_{3}$ : C, 72.71; H, 6.44; N, 4.71. Found: C, 72.55; H, 6.61; N, 4.77; IR $\left(\mathrm{KBr}, \mathrm{cm}^{-1}\right) 3353,2915,1699,1666,1639,1570,1532 ;{ }^{1} \mathrm{H}-\mathrm{NMR}\left(300 \mathrm{MHz}, \mathrm{CDCl}_{3}\right) \delta 1.48(4 \mathrm{H}$, m, 7'- $\left.-\mathrm{CH}_{2}, 8^{\prime}-\mathrm{CH}_{2}\right), 1.73\left(4 \mathrm{H}, \mathrm{m}, 6^{\prime}-\mathrm{CH}_{2}, 9^{\prime}-\mathrm{CH}_{2}\right), 2.51\left(2 \mathrm{H}, \mathrm{m}, 5^{\prime}-\mathrm{CH}_{2}\right), 2.66\left(2 \mathrm{H}, \mathrm{m}, 10^{\prime}-\mathrm{CH}_{2}\right)$, $7.53(3 \mathrm{H}, \mathrm{m}, \mathrm{Ph}), 7.89$ (2H, m, Ph), 8.32 (1H, s, 4'-H), 8.65 (1H, br. s, NH); ${ }^{13} \mathrm{C}-\mathrm{NMR}(75.5$ $\left.\mathrm{MHz}, \mathrm{CDCl}_{3}\right) \delta 25.6,26.0,29.0,29.1,30.2,30.3,116.1,123.4,127.1,127.7,128.9,132.3$, 133.8, 155.2, 160.7, 166.0; MS m/z: $297\left(\mathrm{M}^{+}, 100 \%\right), 241$ (32\%), 105 (84\%).

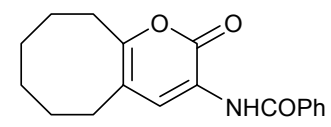

2-[(Z)-(5-oxo-2-phenyloxazol-4(5H)-ylidene)methyl]cyclopent-1-en-1-yl acetate (6a). Mp 172-175 ${ }^{\circ} \mathrm{C}$ (AcOEt); Anal. Calcd. $\mathrm{C}_{17} \mathrm{H}_{15} \mathrm{NO}_{4}$ : C, 68.68; H, 5.09; N, 4.71. Found: C, 68.81; H, 4.93; N, 4.67; IR (KBr, cm $\left.{ }^{-1}\right) 1775,1755,1640,1610 ;{ }^{1} \mathrm{H}-\mathrm{NMR}\left(300 \mathrm{MHz}, \mathrm{CDCl}_{3}\right) \delta 2.08(2 \mathrm{H}$, m, 4'- $\left.\mathrm{CH}_{2}\right), 2.27(3 \mathrm{H}, \mathrm{s}, \mathrm{Ac}), 2.79\left(2 \mathrm{H}, \mathrm{m}, 3^{\prime}-\mathrm{CH}_{2}\right), 3.07\left(2 \mathrm{H}, \mathrm{m}, 5\right.$ '- $\left.\mathrm{CH}_{2}\right), 7.15(1 \mathrm{H}, \mathrm{s},-\mathrm{CH}=)$, $7.53(3 \mathrm{H}, \mathrm{m}, \mathrm{Ph}), 8.07$ (2H, m, Ph); ${ }^{13} \mathrm{C}-\mathrm{NMR}\left(75.5 \mathrm{MHz}, \mathrm{CDCl}_{3}\right) \delta 20.7,21.0,30.0,32.2$, 123.3, 124.0, 125.9, 128.0, 128.9, 132.6, 132.9, 160.5, 161.7, 167.6, 168.0; MS m/z: $297\left(\mathrm{M}^{+}\right.$, $5 \%), 105(100 \%)$.

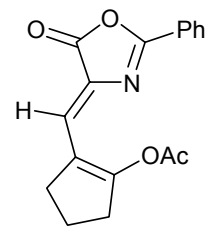

2-[(Z)-(5-oxo-2-phenyloxazol-4(5H)-ylidene)methyl]cyclohex-1-en-1-yl acetate (6b). Mp 164-166 ${ }^{\circ} \mathrm{C}$ (AcOEt); Anal. Calcd. $\mathrm{C}_{18} \mathrm{H}_{17} \mathrm{NO}_{4}$ : C, 69.44; H, 5.50; N, 4.50. Found: C, 69.06; H, 5.32; N, 4.59; IR (KBr, cm $\left.{ }^{-1}\right) 1780,1745,1640,1610 ;{ }^{1} \mathrm{H}-\mathrm{NMR}\left(300 \mathrm{MHz}, \mathrm{CDCl}_{3}\right) \delta 1.79(4 \mathrm{H}$, m, 4'- $\left.\mathrm{CH}_{2}, 5^{\prime}-\mathrm{CH}_{2}\right), 2.27(3 \mathrm{H}, \mathrm{s}, \mathrm{Ac}), 2.42\left(2 \mathrm{H}, \mathrm{m}, 3\right.$ ' $\left.-\mathrm{CH}_{2}\right), 2.95\left(2 \mathrm{H}, \mathrm{m}, 6{ }^{\prime}-\mathrm{CH}_{2}\right), 7.17(1 \mathrm{H}, \mathrm{s}$, $-\mathrm{CH}=), 7.52(3 \mathrm{H}, \mathrm{m}, \mathrm{Ph}), 8.08(2 \mathrm{H}, \mathrm{m}, \mathrm{Ph}) ;{ }^{13} \mathrm{C}-\mathrm{NMR}\left(75.5 \mathrm{MHz}, \mathrm{CDCl}_{3}\right) \delta 21.0,22.05,22.09$, 26.6, 29.0, 123.4, 125.9, 126.4, 128.1, 128.9, 132.6, 133.0, 156.6, 161.9, 168.1, 168.6; MS m/z: $311\left(\mathrm{M}^{+}, 6 \%\right), 105(100 \%)$. 


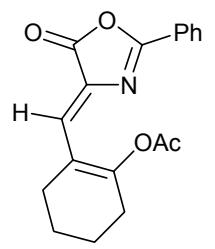

3-Amino-6,7-dihydrocyclopenta[b]pyran-2(5H)-one (7a). This compound $(0.600 \mathrm{~g}$, 79\%) was obtained as a brown solid $\left(\mathrm{EtOH} / \mathrm{H}_{2} \mathrm{O}\right), \mathrm{mp} 175-178{ }^{\circ} \mathrm{C}$; Anal. Calcd. $\mathrm{C}_{8} \mathrm{H}_{9} \mathrm{NO}_{2}$ : C, 63.56; H, 6.00; N, 9.27. Found: C, 63.70; H, 6.12; N, 9.16; IR (KBr, $\left.\mathrm{cm}^{-1}\right) 3451,3349,2928,2860,1691$, 1634, 1611, 1551; ${ }^{1} \mathrm{H}-\mathrm{NMR}\left(300 \mathrm{MHz}, \mathrm{DMSO}-d_{6}\right) \delta 1.98\left(2 \mathrm{H}, \mathrm{m}, \mathrm{CH}_{2}\right), 2.51\left(2 \mathrm{H}, \mathrm{m}, \mathrm{CH}_{2}\right), 2.64$ $\left(2 \mathrm{H}, \mathrm{m}, \mathrm{CH}_{2}\right), 5.12\left(2 \mathrm{H}\right.$, br. s, $\left.\mathrm{NH}_{2}\right), 6.35(1 \mathrm{H}, \mathrm{s}, 4-\mathrm{H}) ;{ }^{13} \mathrm{C}-\mathrm{NMR}\left(75.5 \mathrm{MHz}, \mathrm{DMSO}-d_{6}\right) \delta 20.3$, 28.0, 29.4, 109.6, 116.2, 131.8, 148.2, 160.7; MS m/z: $151\left(\mathrm{M}^{+}, 100 \%\right), 122$ (93\%).

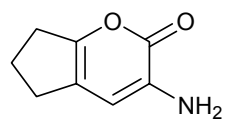

3-Amino-5,6,7,8-tetrahydro-2H-chromen-2-one (7b). This compound (0.760 g, 92\%) was obtained as brown crystals $\left(\mathrm{EtOH} / \mathrm{H}_{2} \mathrm{O}\right), \mathrm{mp} 148-151{ }^{\circ} \mathrm{C}$; Anal. Calcd. $\mathrm{C}_{9} \mathrm{H}_{11} \mathrm{NO}_{2}$ : C, 65.44; $\mathrm{H}$, 6.71; N, 8.48. Found: C, 65.54; H, 6.65; N, 8.36; IR (KBr, $\left.\mathrm{cm}^{-1}\right) 3458,3356,2944,1686,1632$, 1549; ${ }^{1} \mathrm{H}-\mathrm{NMR}\left(300 \mathrm{MHz}, \mathrm{DMSO}-d_{6}\right) \delta 1.55-1.74\left(4 \mathrm{H}, \mathrm{m}, 2 \times \mathrm{CH}_{2}\right), 2.27\left(2 \mathrm{H}, \mathrm{m}, \mathrm{CH}_{2}\right), 2.37$ $\left(2 \mathrm{H}, \mathrm{m}, \mathrm{CH}_{2}\right), 5.07\left(2 \mathrm{H}\right.$, br. s, $\left.\mathrm{NH}_{2}\right), 6.11\left(1 \mathrm{H}\right.$, br. s, 4-H); ${ }^{13} \mathrm{C}-\mathrm{NMR}\left(75.5 \mathrm{MHz}, \mathrm{DMSO}-d_{6}\right) \delta$ 21.65, 21.71, 25.3, 25.8, 112.5, 112.9, 132.0, 145.2, 159.9; MS m/z: $165\left(\mathrm{M}^{+}, 83 \%\right), 109$ (100\%).

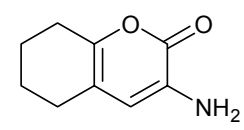

3-Amino-6,7,8,9-tetrahydrocyclohepta[b]pyran-2(5H)-one (7c). This compound (0.752 g, 84\%) was obtained as pale yellow crystals (AcOEt/light petroleum), mp 118-121 ${ }^{\circ} \mathrm{C}$; Anal. Calcd. $\mathrm{C}_{10} \mathrm{H}_{13} \mathrm{NO}_{2}$ : C, 67.02; H, 7.31; N, 7.82. Found: C, 67.24; H, 7.20; N, 7.97; IR (KBr, cm $\left.{ }^{-1}\right)$ 3460, 3345, 2930, 1690, 1634, 1556; ${ }^{1} \mathrm{H}-\mathrm{NMR}\left(300 \mathrm{MHz}, \mathrm{CDCl}_{3}\right) \delta 1.61\left(4 \mathrm{H}, \mathrm{m}, 2 \times \mathrm{CH}_{2}\right), 1.77$ $\left(2 \mathrm{H}, \mathrm{m}, \mathrm{CH}_{2}\right), 2.39\left(2 \mathrm{H}, \mathrm{m}, \mathrm{CH}_{2}\right), 2.65\left(2 \mathrm{H}, \mathrm{m}, \mathrm{CH}_{2}\right), 3.88\left(2 \mathrm{H}\right.$, br. s, $\left.\mathrm{NH}_{2}\right), 6.25(1 \mathrm{H}, \mathrm{s}, 4-\mathrm{H})$; ${ }^{13} \mathrm{C}-\mathrm{NMR}\left(75.5 \mathrm{MHz}, \mathrm{CDCl}_{3}\right) \delta 25.2,26.9,31.55,31.62,33.2,118.1,118.6,130.2,152.9,160.8$; MS $m / z: 179\left(\mathrm{M}^{+}, 100 \%\right), 122(65 \%)$.

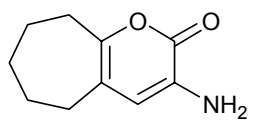

3-Amino-5,6,7,8,9,10-hexahydro-2H-cycloocta[b]pyran-2-one (7d). This compound (0.860 g, $89 \%$ ) was obtained as pale yellow crystals (AcOEt/light petroleum), mp 71-74 ${ }^{\circ} \mathrm{C}$; Anal. Calcd. $\mathrm{C}_{11} \mathrm{H}_{15} \mathrm{NO}_{2}$ : C, 68.37; H, 7.82; N, 7.25. Found: C, 68.28; H, 7.78; N, 7.34; IR (KBr, cm $\left.{ }^{-1}\right) 3435$, 3331, 2924, 2852, 1686, 1636, 1611, 1546; ${ }^{1} \mathrm{H}-\mathrm{NMR}\left(300 \mathrm{MHz}, \mathrm{CDCl}_{3}\right) \delta 1.37-1.50(4 \mathrm{H}, \mathrm{m}$, 
$\left.2 \times \mathrm{CH}_{2}\right), 1.57-1.73\left(4 \mathrm{H}, \mathrm{m}, 2 \times \mathrm{CH}_{2}\right), 2.36\left(2 \mathrm{H}, \mathrm{m}, \mathrm{CH}_{2}\right), 2.57\left(2 \mathrm{H}, \mathrm{m}, \mathrm{CH}_{2}\right), 3.90(2 \mathrm{H}$, br. s, $\left.\mathrm{NH}_{2}\right), 6.22(1 \mathrm{H}, \mathrm{s}, 4-\mathrm{H}) ;{ }^{13} \mathrm{C}-\mathrm{NMR}\left(75.5 \mathrm{MHz}, \mathrm{CDCl}_{3}\right) \delta 25.3,25.7,28.6,28.9,29.4,30.0$, 115.5, 116.8, 131.0, 149.9, 161.2; MS m/z: $193\left(\mathrm{M}^{+}, 100 \%\right), 122$ (77\%).

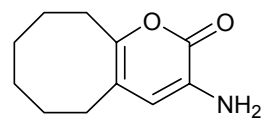

$\boldsymbol{N}$-[6-Methyl-5-(4-methoxyphenyl)-2-oxo-2H-pyran-3-yl]benzamide (10a). The compound (23.34 g, 81\%) was obtained as pale brown needles $\left(\mathrm{EtOH} / \mathrm{CH}_{2} \mathrm{Cl}_{2}\right), \mathrm{mp} 151-155{ }^{\circ} \mathrm{C}$; Anal. Calcd. $\mathrm{C}_{20} \mathrm{H}_{17} \mathrm{NO}_{4}$ : C, 71.63; H, 5.11; N, 4.18. Found: C, 71.40; H, 4.95; N, 4.17; IR (KBr, cm $\left.{ }^{-1}\right)$ 3386, 1711, 1666, 1607, 1511; ${ }^{1} \mathrm{H}-\mathrm{NMR}\left(300 \mathrm{MHz}, \mathrm{CDCl}_{3}\right) \delta 2.29$ (3H, s, 6'-Me), 3.85 (3H, s, OMe), 6.96 (2H, AA'XX') and 7.24 (2H, AA'XX') (2"-H, 3"-H, 5"-H, 6"-H), 7.53 (3H, m, Ph), $7.89(2 \mathrm{H}, \mathrm{m}, \mathrm{Ph}), 8.49\left(1 \mathrm{H}, \mathrm{s}, 4{ }^{\prime}-\mathrm{H}\right), 8.66\left(1 \mathrm{H}\right.$, br. s, NH); ${ }^{13} \mathrm{C}-\mathrm{NMR}\left(75.5 \mathrm{MHz}, \mathrm{CDCl}_{3}\right) \delta 17.9$, $55.4,114.2$, 118.4, 123.0, 127.1, 127.9, 128.3, 128.9, 130.2, 132.4, 133.8, 151.6, 159.3, 160.1, 166.0; MS m/z: $335\left(\mathrm{M}^{+}, 55 \%\right), 105(100 \%)$.

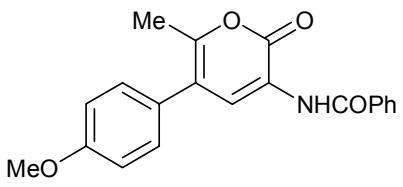

$\mathrm{N}$-[5-(3,4-Dimethoxyphenyl)-6-methyl-2-oxo-2H-pyran-3-yl]benzamide $\quad$ (10b). The compound (24.48 g, 78\%) was obtained as brown needles (EtOH), mp 161-162 ${ }^{\circ} \mathrm{C}$; Anal. Calcd. $\mathrm{C}_{21} \mathrm{H}_{19} \mathrm{NO}_{5}$ : C, 69.03; H, 5.24; N, 3.83. Found: C, 68.82; H, 5.29; N, 4.09; IR (KBr, cm $\left.{ }^{-1}\right) 3405$, 1709, 1665, 1510br; ${ }^{1} \mathrm{H}-\mathrm{NMR}\left(300 \mathrm{MHz}, \mathrm{CDCl}_{3}\right) \delta 2.30$ (3H, s, 6'-Me), 3.91 (3H, s, OMe), 3.93 (3H, s, OMe), 6.84 (3H, m), 7.53 (3H, m), 7.89 (2H, m) (Ph, 2"-H, 5"-H, 6"-H), 8.49 (1H, s, 4'$\mathrm{H}), 8.67\left(1 \mathrm{H}\right.$, br. s, NH); ${ }^{13} \mathrm{C}-\mathrm{NMR}\left(75.5 \mathrm{MHz}, \mathrm{CDCl}_{3}\right) \delta 17.8,55.80,55.88,111.1,112.0,118.3$, $121.4,122.7,126.9,127.5,128.4,128.7,132.2,133.5,148.7,148.9,151.5,159.8,165.8$; MS $m / z: 365\left(\mathrm{M}^{+}, 40 \%\right), 105(100 \%)$.

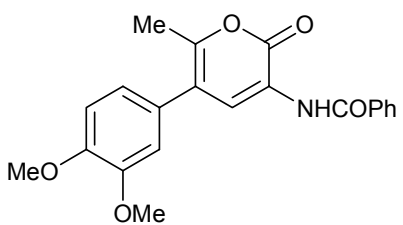

3-Amino-6-methyl-2H-pyran-2-one (12a). This compound (0.562 g, 90\%) was obtained as pale orange cyrstals $\left(\mathrm{H}_{2} \mathrm{O}\right)$, mp $123-124{ }^{\circ} \mathrm{C}$; Anal. Calcd. $\mathrm{C}_{6} \mathrm{H}_{7} \mathrm{NO}_{2}$ : C, 57.59; H, 5.64; N, 11.19. Found: C, 57.52; H, 5.59; N, 10.96; IR (KBr, cm $\left.{ }^{-1}\right) 3424,3337,1697,1639,1558 ;{ }^{1} \mathrm{H}-\mathrm{NMR}(300$ MHz, DMSO- $\left.d_{6}\right) \delta 2.10\left(3 \mathrm{H}\right.$, deg. d, Me), $5.08\left(2 \mathrm{H}\right.$, br. s, $\left.\mathrm{NH}_{2}\right), 5.96(1 \mathrm{H}, \mathrm{deg} . \mathrm{dq}, 5-\mathrm{H}), 6.25$ 
$(1 \mathrm{H}, \mathrm{d}, J=7.0 \mathrm{~Hz}, 4-\mathrm{H}) ;{ }^{13} \mathrm{C}-\mathrm{NMR}\left(75.5 \mathrm{MHz}, \mathrm{DMSO}-d_{6}\right) \delta 18.3,104.0,110.6,131.8,147.8$, 160.2; MS m/z: $125\left(\mathrm{M}^{+}, 100 \%\right), 96(98 \%)$.

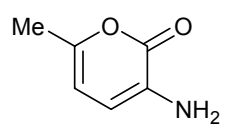

3-Amino-6-phenyl-2H-pyran-2-one (12b). This compound (0.832 g, 89\%) was obtained as orange needles $\left(\mathrm{EtOH} / \mathrm{H}_{2} \mathrm{O}\right), \mathrm{mp} 95-98{ }^{\circ} \mathrm{C}\left(\mathrm{mp}^{14} 102-103{ }^{\circ} \mathrm{C}\right.$, from benzene/light petroleum); Anal. Calcd. $\mathrm{C}_{11} \mathrm{H}_{9} \mathrm{NO}_{2}$ : C, 70.58; H, 4.85; N, 7.48. Found: C, 70.86; H, 4.94; N, 7.49; IR (KBr, $\mathrm{cm}^{-1}$ ) 3440, 3408, 3348, 1699, 1636; ${ }^{1} \mathrm{H}-\mathrm{NMR}\left(300 \mathrm{MHz}, \mathrm{DMSO}-d_{6}\right) \delta 5.60\left(2 \mathrm{H}, \mathrm{br} . \mathrm{s}, \mathrm{NH}_{2}\right)$, $6.43(1 \mathrm{H}, \mathrm{d}, J=7.5 \mathrm{~Hz}), 6.91(1 \mathrm{H}, \mathrm{d}, J=7.5 \mathrm{~Hz})(4-\mathrm{H}, 5-\mathrm{H}), 7.32(1 \mathrm{H}, \mathrm{m}, \mathrm{Ph}), 7.43(2 \mathrm{H}, \mathrm{m}, \mathrm{Ph})$, $7.68(2 \mathrm{H}, \mathrm{m}, \mathrm{Ph}) ;{ }^{13} \mathrm{C}-\mathrm{NMR}\left(75.5 \mathrm{MHz}, \mathrm{DMSO}-d_{6}\right) \delta 103.7,110.0,123.1,128.0,128.8,132.0$, 133.7, 146.4, 159.2; MS m/z: $187\left(\mathrm{M}^{+}, 100 \%\right), 159$ (75\%).

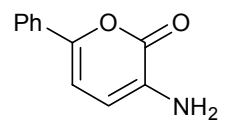

3-Amino-6-tert-butyl-2H-pyran-2-one (12c). This compound (0.810 g, 97\%) was obtained as pale yellow fine cyrstals $\left(\mathrm{Et}_{2} \mathrm{O}\right), \mathrm{mp} 55-57.5^{\circ} \mathrm{C}$; IR $\left(\mathrm{KBr}, \mathrm{cm}^{-1}\right) 3462,3355,2966,1692,1636$, 1557; ${ }^{1} \mathrm{H}-\mathrm{NMR}\left(300 \mathrm{MHz}, \mathrm{DMSO}-d_{6}\right) \delta 1.17$ (s, 9H, $t$-Bu), $5.13\left(2 \mathrm{H}, \mathrm{br} . \mathrm{s}, \mathrm{NH}_{2}\right), 5.99(1 \mathrm{H}, \mathrm{d}, J$ $=7.3 \mathrm{~Hz}), 6.29(1 \mathrm{H}, \mathrm{d}, J=7.3 \mathrm{~Hz})(4-\mathrm{H}, 5-\mathrm{H}) ;{ }^{13} \mathrm{C}-\mathrm{NMR}\left(75.5 \mathrm{MHz}, \mathrm{DMSO}-d_{6}\right) \delta 27.9,34.5$, 100.1, 110.3, 132.0, 158.1, 160.0; MS m/z: $167\left(\mathrm{M}^{+}, 48 \%\right), 152$ (100\%). HRMS Calcd. $\mathrm{C}_{9} \mathrm{H}_{13} \mathrm{NO}_{2}$ : 167.0946. Found: 167.0950 .

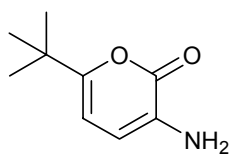

3-Amino-6-(2-pyridyl)-2H-pyran-2-one (12d). This compound (0.884 g, 94\%) was obtained as pale brown solid $\left(\mathrm{H}_{2} \mathrm{O}\right)$, mp $144-146{ }^{\circ} \mathrm{C}$; Anal. Calcd. $\mathrm{C}_{10} \mathrm{H}_{8} \mathrm{~N}_{2} \mathrm{O}_{2}$ : C, 63.83; H, 4.28; N, 14.89 . Found: C, 63.76; H, 4.39; N, 14.94; IR (KBr, cm $\left.{ }^{-1}\right) 3444,3345,1682,1635,1605,1581,1567$; ${ }^{1} \mathrm{H}-\mathrm{NMR}\left(300 \mathrm{MHz}, \mathrm{DMSO}-d_{6}\right) \delta 5.85\left(2 \mathrm{H}\right.$, br. s, $\left.\mathrm{NH}_{2}\right), 6.47(1 \mathrm{H}, \mathrm{d}, J=7.5 \mathrm{~Hz}, 4-\mathrm{H}), 7.23(1 \mathrm{H}$, $\mathrm{d}, J=7.5 \mathrm{~Hz}, 5-\mathrm{H}), 7.30(1 \mathrm{H}, \mathrm{ddd}, J=1.2,4.7,7.5 \mathrm{~Hz}, 5 '-\mathrm{H}), 7.68(1 \mathrm{H}$, ddd, $J=1.0,1.2,8.1 \mathrm{~Hz}$, 3'-H), $7.86\left(1 \mathrm{H}, \mathrm{ddd}, J=1.7,7.5,8.1 \mathrm{~Hz}, 4{ }^{\prime}-\mathrm{H}\right), 8.56\left(1 \mathrm{H}, \mathrm{ddd}, J=1.0,1.9,4.7 \mathrm{~Hz}, 6{ }^{\prime}-\mathrm{H}\right)$; ${ }^{13} \mathrm{C}-$ NMR (75.5 MHz, DMSO- $\left.d_{6}\right) \delta 105.8,109.2,117.4,122.6,135.2,137.3,145.6,149.3,149.6$, 158.7; MS m/z: $188\left(\mathrm{M}^{+}, 100 \%\right)$.

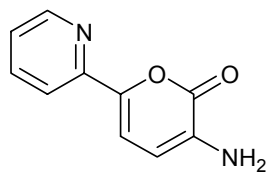


3-Amino-4-methyl-6-(2-pyridyl)-2H-pyran-2-one (12e). This compound (0.788 g, 78\%) was obtained as pale brown solid (EtOH), mp 186.5-187 ${ }^{\circ} \mathrm{C}$; Anal. Calcd. $\mathrm{C}_{11} \mathrm{H}_{10} \mathrm{~N}_{2} \mathrm{O}_{2}$ : C, 65.34; H, 4.98; N, 13.85. Found: C, 65.55; H, 5.02; N, 13.86; IR (KBr, cm $\left.{ }^{-1}\right) 3379,3281,3213,1686$, 1632; ${ }^{1} \mathrm{H}-\mathrm{NMR}\left(300 \mathrm{MHz}, \mathrm{DMSO}-d_{6}\right) \delta 2.10(3 \mathrm{H}, \mathrm{s}, \mathrm{Me}), 5.49\left(2 \mathrm{H}, \mathrm{br} . \mathrm{s}, \mathrm{NH}_{2}\right), 7.20$ (1H, s, 5H), $7.31(1 \mathrm{H}, \mathrm{ddd}, J=1.1,4.7,7.5 \mathrm{~Hz}, 5 '-\mathrm{H}), 7.70\left(1 \mathrm{H}, \mathrm{ddd}, J=1.0,1.1,8.0 \mathrm{~Hz}, 3^{\prime}-\mathrm{H}\right), 7.87(1 \mathrm{H}$, $\left.\mathrm{ddd}, J=2.0,7.5,8.0 \mathrm{~Hz}, 4^{\prime}-\mathrm{H}\right), 8.59$ (1H, ddd, $\left.J=1.0,2.0,4.7 \mathrm{~Hz}, 6{ }^{\prime}-\mathrm{H}\right) ;{ }^{13} \mathrm{C}-\mathrm{NMR}(75.5 \mathrm{MHz}$, DMSO- $\left.d_{6}\right) \delta 16.3,109.0,117.6,120.1,122.7,131.6,137.2,144.6,149.1,149.5,158.5 ; \mathrm{MS} \mathrm{m} / \mathrm{z}$ : $202\left(\mathrm{M}^{+}, 100 \%\right), 79(47 \%)$.

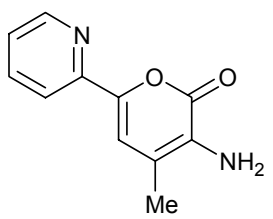

\section{Acknowledgements}

We thank the Ministry of Higher Education, Science and Technology of the Republic of Slovenia as well as the Slovenian Research Agency for financial support (P1-0230-0103 and J16693-0103). Dr. B. Kralj and Dr. D. Žigon (Center for Mass Spectroscopy, "Jožef Stefan" Institute, Ljubljana, Slovenia) are gratefully acknowledged for mass measurements.

\section{References and Notes}

1. (a) Hepworth, J. D. In Comprehensive Heterocyclic Chemistry: Pyrans and Fused Pyrans: (iii) Synthesis and Applications; Katritzky, A. R.; Rees, C. W. Eds.; Pergamon Press: Oxford, 1984; Vol. 3, pp 737-883. (b) Hepworth, J. D.; Gabbutt, C. D.; Heron, B. M. In Comprehensive Heterocyclic Chemistry II: Pyrans and their Benzo Derivatives: Synthesis; Katritzky, A. R.; Rees, C. W.; Scriven, E. F. V. Eds.; Pergamon Press: Oxford, 1996; Vol. 5, pp 351-468. (c) Geen, G. R.; Evans, J. M.; Vong, A. K. In Comprehensive Heterocyclic Chemistry II: Pyrans and their Benzo Derivatives: Applications; Katritzky, A. R.; Rees, C. W.; Scriven, E. F. V. Eds.; Pergamon Press: Oxford, 1996; Vol. 5, pp 469-500. (d) Afarinkia, K.; Vinader, M. V. In: Science of Synthesis; Thomas, E. J. Ed.; Thieme: Stuttgart, 2003; Vol. 14, pp 275-346.

2. (a) Ellis, G. P. In Comprehensive Heterocyclic Chemistry: Pyrans and Fused Pyrans: (ii) Reactivity; Katritzky, A. R.; Rees, C. W. Eds.; Pergamon Press: Oxford, 1984; Vol. 3, pp 647-736. (b) Ram, V. J.; Srivastava, P. Curr. Org. Chem. 2001, 5, 571. (c) Hepworth, J. D.; Heron, B. M. In Progress in Heterocyclic Chemistry; Gribble, G. W.; Joule, J. A. Eds.; 
Elsevier: Amsterdam, 2005; Vol 17, pp 33-62.

3. For reviews, see: (a) Afarinkia, K.; Vinader, V.; Nelson, T. D.; Posner, G. H. Tetrahedron 1992, 48, 9111. (b) Woodard, B. T.; Posner, G. H. In Advances in Cycloaddition; Harmata, M. Ed.; JAI Press Inc.: Greenwich, 1999; Vol. 5, pp 47-83.

4. (a) Kranjc, K.; Leban, I.; Polanc, S.; Kočevar, M. Heterocycles 2002, 58, 183. (b) Martelanc, M.; Kranjc, K.; Polanc, S.; Kočevar, M. Green Chem. 2005, 7, 737. (c) Kranjc, K.; Polanc, S.; Kočevar, M. Org. Lett. 2003, 5, 2833. (d) Kranjc, K.; Kočevar, M.; Iosif, F.; Coman, S. M.; Parvulescu, V. I.; Genin, E.; Genêt, J.-P.; Michelet, V. Synlett 2006, 1075. (e) Kranjc, K.; Štefane, B.; Polanc, S.; Kočevar, M. J. Org. Chem. 2004, 69, 3190. (f) Kranjc, K.; Kočevar, M. New J. Chem. 2005, 29, 1027. (g) Kranjc, K.; Kočevar, M. Collect. Czech. Chem. Commun. 2006, 71, 667.

5. (a) Kafka, S.; Trebše, P.; Polanc, S.; Kočevar, M. Synlett 2000, 254. (b) Požgan, F.; Polanc, S.; Kočevar, M. Tetrahedron 2006, 62, 9718. (c) Požgan, F.; Kafka, S.; Polanc, S.; Kočevar, M. Heterocycles 2006, 70, In Press (Published online, 29 August, 2006. COM-06-S(W)11).

6. (a) Kočevar, M.; Polanc, S.; Tišler, M.; Verček, B. Synth. Commun. 1989, 19, 1713. (b) Kepe, V.; Kočevar, M.; Polanc, S.; Verček, B.; Tišler, M. Tetrahedron 1990, 46, 2081. (c) Kočevar, M.; Polanc, S.; Verček, B.; Tišler, M. Liebigs Ann. Chem. 1990, 501. (d) Kepe, V.; Kočevar, M.; Petrič, A.; Polanc, S.; Verček, B. Heterocycles 1992, 33, 843. (e) Kepe, V.; Kočevar, M.; Polanc, S. Heterocycles 1995, 41, 1299. (f) Kepe, V.; Kočevar, M.; Polanc, S. J. Heterocycl. Chem. 1996, 33, 1707. (g) Kepe, V.; Polanc, S.; Kočevar, M. Heterocycles 1998, 48, 671 .

7. (a) Minardi, G.; Schenone, P.; Bignardi, G. Ann. Chim. (Rome) 1968, 58, 1320; Chem. Abstr. 1969, 70, 96728n. (b) Schuda, P. F.; Ebner, C. B.; Morgan, T. M. Tetrahedron Lett. 1986, 27, 2567. (c) Murahashi, S.-I.; Mitsue, Y.; Tsumiyama, T. Bull. Chem. Soc. Jpn. 1987, 60, 3285. (d) Zhuo, J.-C. Magn. Reson. Chem. 1996, 34, 595.

8. (a) Prokof'ev, E. P.; Karpeiskaya, E. I. Tetrahedron Lett. 1979, 737. (b) Dobnikar M.; Kočevar, M.; Polanc, S.; Tišler, M.; Verček, B. Heterocycles 1989, 29, 281. (c) Kepe, V.; Kočevar, M.; Polanc, S. Heterocycles 1993, 35, 955. (d) Morgenstern, A. P.; Schutij, C.; Nauta, W. Th. J. Chem. Soc., Chem. Commun. 1969, 321.

9. Behringer, H.; Falkenberg, K. Chem. Ber. 1963, 96, 1428.

10. (a) Microwaves in Organic Synthesis; Loupy, A. Ed.; Wiley-VCH: Weinheim, 2002. (b) Hayes, B. L. Microwave Synthesis: Chemistry at the Speed of Light; CEM Publishing: Matthews, NC, 2002. (c) Lidström, P.; Tierney, J.; Wathey, B.; Westman, J. Tetrahedron 2001, 42, 9225. (d) Varma, R. S. Green Chem. 1999, 1, 43. (e) Kappe, C. O. Angew. Chem. Int. Ed. 2004, 43, 6250. (f) de la Hoz, A.; Díaz-Ortiz, Á.; Moreno, A. Chem. Soc. Rev. 2005, 34, 164. (g) El Ashry, E. S. H.; Kassem, A. A. ARKIVOC 2006, (ix), 1.

11. See, for example: (a) Ješelnik, M.; Varma, R. S.; Polanc, S.; Kočevar, M. Chem. Commun. 2001, 1716. (b) Ješelnik, M.; Varma, R. S.; Polanc, S.; Kočevar, M. Green Chem. 2002, 4, 35. (c) Pospíšil, J.; Potáček, M. Eur. J. Org. Chem. 2004, 710. (d) Anwar, H. F.; Metwally, N. H.; Gaber, H.; Elnagdi, M. H. J. Chem. Res. (S) 2005, 29. (e) Katritzky, A. R.; Cai, C. 
M.; Collins, M. D.; Scriven, E. F. V.; Singh, S. K.; Barnhardt, E. K. J. Chem. Educ. 2006, 83, 634. (f) Marković, R.; Pergal, M. M.; Baranac, M.; Stanisavljev, D.; Stojanović, M. ARKIVOC 2006, (ii), 83.

12. (a) Clark, B. P.; Ross, W. J.; Todd, A. Ger. Offen. 3,012,597, 1980, 39 pp.; Chem. Abstr. 1981, 94, 83945b. (b) Lesher, G. Y.; Opalka, C. J., Jr.; Page, D. F.; McGarry, R. M. U. S. US 4,465,686, 1984, 9 pp; Chem. Abstr. 1984, 101, 191710 t.

13. (a) Kočevar, M. Acta Chim. Slov. 1996, 43, 143. (b) Trebše, P.; Vraničar, V.; Mušič, I.; Polanc, S.; Stevens, W. C.; Kočevar, M. Heterocycles 2000, 53, 1111. (c) Požgan, F.; Krejan, M.; Polanc, S.; Kočevar, M. Heterocycles 2006, 69, In Press (Published online, 27 January, 2006. COM-05-S(O)1).

14. Shusherina, N. P.; Dmitrieva, N. D.; Komarovskaya, G. V.; Levina, R. Ya. Zh. Org. Khim. 1968, 4, 2048; Chem. Abstr. 1969, 70, 28759y. 